\title{
Tutkijat geopoliittisten narratiivien äärellä
}

Aleksanteri-instituutissa järjestettiin 3.-4. lokakuuta 2019 "Geopolitics of Culture and Displacement" -seminaari, joka keräsi täyden salillisen tutkijoita ja kiinnostunutta yleisöä. Seminaarissa esiintyvä kansainvälinen puhujajoukko koostui paitsi Suomen eri yliopistoissa myös Venäjän, Euroopan eri maissa, Azerbaidžanissa sekä Yhdysvalloissa toimivista tutkijoista. Esitelmissä tarkasteltiin monipuolisesti kulttuurin käytäntöihin kietoutuvia geopoliittisia narratiiveja sekä niissä esille tulevaa vallan ja toimijuuden vuorovaikutusta erityisesti Venäjällä, Itä-Euroopassa ja Euraasian alueella. Toinen seminaarin painopisteistä oli edellä mainittujen aiheiden kytkeytyminen yksilöiden ja väestöryhmien migraation ja marginalisaation kysymyksiin. Esitelmien lisäksi kaksipäiväisen seminaarin ohjelma koostui Jason Dittmerin (University College London) keynoteluennosta sekä torstaina järjestetystä illallisesta. Seminaarin yleistunnelma oli hyväntuulinen ja innostunut, ja seminaariesitelmät herättivät kuulijoissa aktiivista keskustelua.

Seminaarin avasi järjestelytoimikunnan puheenjohtaja ja Aleksanteri-instituutin vanhempi tutkija Sanna Turoma, joka pohjusti seminaarin aihetta vertailemalla eri kielialueiden tapoja ymmärtää ja käyttää geopolitiikka-käsitettä. Kuten Turoma totesi, Neuvostoliitossa geopolitiikka ei ollut virallisesti hyväksytty tutkimusala vaan sitä pidettiin "taantumuksellisena teoriana", jota "imperialistiset valtiot" harjoittivat. NykyVenäjällä geopolitiikka on yliopistojen oppiaine ja käsite, jonka avulla pyritään määrittelemään Venäjän asemaa Neuvostoliiton hajoamisen myötä muuttuneella maailmanpoliittisella kartalla. Englanninkielisessä tutkimusmaailmassa geopolitiikan lähestymistavat ovat tuottaneet niin sanotun kriittisen geopolitiikan suuntauksen jälkistrukturalismin sekä feministisen että jälkikolonialistisen teorian vaikutuksesta. Turoman mukaan käsillä olevan seminaarin tarkoituksena olikin laajentaa geopolitiikka-käsitteen käyttöä käytännön politiikan tarkastelusta siihen, miten geopolitiikan narratiivit ja niihin liittyvät valtasuhteet nousevat esiin kulttuurin tuotteiden ja ilmiöiden tasolla.

Seminaarissa kuullut esitelmät vastasivat Turoman aloituspuheenvuorossa esittämään haasteeseen geopoliittisten narratiivien, val- tasuhteiden ja kulttuuristen ilmiöiden välisten suhteiden tarkastelusta lähestymällä aihetta monenlaisista aineistoista käsin. Suurimmaksi yksittäiseksi aineistotyypiksi nousi kaunokirjallinen fiktio, ja geopoliittisia narratiiveja tarkasteltiin niin ukrainan- ja venäjänkielisen kuin latviankielisen ja alkuperäiskansakirjallisuudenkin kautta. Venäjän kielen, kulttuurin ja kääntämisen apulaisprofessori Marja Sorvari Itä-Suomen yliopistosta lähestyi omassa esitelmässään venäläisten naiskirjailijoiden Zinaida Lindénin, Marina Palein ja Ljudmila Ulitskajan kertomuksia emigraatiosta ruumiillisena kokemuksena. Kuten Sorvari esitelmässään osoitti, kaikissa hänen analysoimissaan kertomuksissa nousee esiin, kuinka teosten päähenkilöiden ristiriitaiset kokemukset kansallisesta identiteetistä ilmenevät ennen kaikkea ruumiillisina kokemuksina ja muistijälkinä. Teokset havainnollistavat sitä, kuinka suuret geopoliittiset ja kansalliset narratiivit kätkevät helposti alleen yksilöiden sukupuolittuneita ja ruumiillisia kokemuksia kodista, kotimaasta ja kansallisesta identiteetistä.

Nykykirjallisuuden lisäksi esitelmissä palattiin myös venäläisen kirjallisuuden kultakauteen. Yalen yliopiston slaavilaisten kielten ja kirjallisuuksien professori Edyta Bojanowska käsiteli omassa esitelmässään Aleksandr Puškinin runoa "Klevetnikam Rossii" ("Venäjän parjaajille"). Bojanowska eritteli esitelmässään Puškinin runossa esiintyvää imperialistista ajatusmaailmaa, jossa Venäjä näyttäytyy kaikkien slaavimaiden puolestapuhujana suhteessa länteen ja kiistää muilta Itä-Euroopan mailta mahdollisuuden omaan, itsenäiseen ääneen. Runo esittää muut slaavimaat Venäjän kurittomina pikkusisaruksina, joiden toimiin Venäjällä on historiallinen oikeus ja jopa velvollisuus puuttua. Kuten Bojanowska osoitti, Puškinin runo ja sen länsimaille suuntaama viesti ovat saaneet uutta jalansijaa nykyisessä geopoliittisessa kontekstissa. Erityisesti Krimin valtaus ja tapahtuman lännessä herättämä kritiikki nostavat runon jälleen ajankohtaiseksi ja tuo taas uudet sukupolvet imperialistisen ajatusmaailman äärelle. Siinä muut slaavimaat nähdään Venäjän reviiirinä, jonka sisäisiin asioihin länsimaiden ei tule puuttua.

Kirjallisuuden lisäksi seminaariesitelmissä tarkasteltiin geopoliittisten narratiivien ulottu- 
mista myös muuhun kulttuuriin ja mediaan. Esimerkiksi Kööpenhaminan yliopiston kulttuurinja aluetutkimuksen apulaisprofessori Mikhail Suslov käsitteli paljon keskustelua herättäneessä esitelmässään sosiaalisessa mediassa esiintyviä mielikuvia venäläisistä provinssikaupungeista post-sosialistisena tilana. Suslovin näkemyksen mukaan Venäjän perifeerisiä kaupunkitiloja käsittelevät sosiaalisen median ryhmät estetisoivat kaupunkikuvassa näkyvät merkit epäonnistuneesta kommunistisesta projektista. Samalla ryhmät nostavat kyseisen post-sosialistisen tilan estetiikan venäläisiä yhdistäväksi kokemukseksi pyrkien sen avulla luomaan yhtenäistä kansallista identiteettiä ja nostalgiaan nojaavaa yhteisöllisyyden kokemusta. Myös Justyna Pierzynska Helsingin yliopistosta hyödynsi internet-aineistoa esitelmässään, joka käsitteli geopoliittisten narratiivien ilmenemistä Georgian sotaa ja Krimin valtausta käsittelevissä serbialaisissa internet-keskusteluissa. Pierzynskan tapaustutkimus tarjosikin esimerkin siitä, kuinka suuri rooli affekteilla on geopoliittisen ymmärryksen ja kansallisten narratiivien luomisessa. Kuten Pierzynska esitelmässään osoitti, internetkeskusteluihin osallistuvat kommentoijat kytkivät ymmärryksensä Kaukasuksen ja Krimin alueen kysymyksistä Serbian omiin kokemuksiin Jugoslavian hajoamissodista ja käyttivät kyseisiä kriisejä peilinä oman geopoliittisen aseman määrittämiseksi.

Tatu Laukkanen Tampereen yliopistosta ja Rahim Rahimov Bakun yliopistosta käsittelivät esitelmissään elokuva-aineistoa. Laukkanen analysoi esitelmässään venäläisiä ja kiinalaisia elokuvia toisesta maailmansodasta. Hän näki niiden tuottavan kansallisia sotanarratiiveja, jotka vastustavat Hollywoodissa tuotettujen elokuvien luomaa mielikuvaa Yhdysvalloista maailmanpolitiikan johtohahmona. Samalla elokuvat jäljittelevät kuitenkin Hollywood-elokuvien tyyliä tuottaen kotimaisille elokuvamarkkinoille viihde-elokuvia, jotka kilpailevat omasta markkinaosuudestaan nimenomaan niiden sisältämän nationalistisen eetoksen avulla. Rahimov tarkasteli omassa esitelmässään puolestaan Venäjän vallankumouksen 100-vuotisjuhlavuoden kunniaksi tehtyjä elokuvia ja dokumentteja. Esitelmä pohti sitä, kuinka kyseiset teokset oli tuotettu palvelemaan Venäjän 2010-luvun poliittisia tarpeita erityisesti suhteessa vuonna 2018 pidettyihin presidentinvaaleihin.

Siirtolaisuuteen ja ihmisryhmien liikkumiseen liittyvät geopoliittiset kysymykset olivat myös vahvasti esillä seminaarin esitelmissä. Esitelmissä käsiteltiinkin erityisesti maahan- muuttajien ja muiden marginaalisissa asemissa olevien ihmisryhmien omaa toimijuutta ja sitä edistäviä käytänteitä ja kulttuurisia esityksiä. Daria Krivonos ja Elisa Pascucci Helsingin yliopistosta esittelivät yhteisesitelmässään Nasreddin-taideprojektia, jossa Pietarin kaupunkia lähestytään maahanmuuttajien ja vierastyöläisten näkökulmasta taiteen, tutkimuksen ja aktivismin keinoin. Nasreddin, Lähi-idän kansanperinteessä esiintyvä veijarihahmo, toimii taideprojektin symbolina, sillä kujeilijahahmoihin liittyvä naurun elementti toimii maahanmuuttajille keinona vastustaa ja horjuttaa kohtaamaansa viranomaisvalvontaa ja rasistisia käytänteitä.

Rustamjon Urinboyev Helsingin yliopistosta käsitteli esitelmässään sitä, millaisia mahdollisuuksia älypuhelimet tarjoavat Moskovan uzbekki-työläisille ympäristöön kiinnittymisen tueksi. Urinboyevin mukaan vierastyöläisten kokoontuminen julkisilla paikoilla on usein haasteellista erityisesti virkavallasta johtuvien rajoitteiden takia. Näin ollen älylaitteista ja sosiaalisesta mediasta on tullut vierastyöläisille keino luoda ja ylläpitää transnationaalista yhteisöllisyyttä. Viestintäteknologia yhdistää Moskovassa samalta kotiseudulta tulleita vierastyöläisiä ja luo tukiverkoston, joka auttaa vierastyöläisiin kohdistuvien ongelmien ja riskien selättämisessä. Toisaalta älypuhelimet ja sosiaalinen media ylläpitävät ja toisintavat kotiseudun kulttuurisia normeja ja velvoitteita Moskovaan luotujen yhteisöjen keskuudessa.

Myös Jason Dittmer käsitteli keynote-luennossaan migraation problematiikkaa populaarin geopolitiikan keinoin lähestyen aihetta supersankarielokuvista käsin. Molemmat Dittmerin käsittelemät elokuvat ovat Hollywoodin 2010-luvun lopulla tuottamia kaupallisia myyntimenestyksiä, mutta kuten Dittmerin analyysi elokuvista osoitti, elokuvia on mahdollista lukea tapana käsitellä maailmaa kohdannutta pakolaiskriisiä. Dittmer kytki elokuvien analyysin kansainvälisesti kiristyneisiin asenteisiin maahanmuuttoa ja pakolaisia kohtaan sekä näihin kohdistuvaan turvallistamispuheeseen ja -toimenpiteisiin. Dittmer osoittikin luennossaan, kuinka hänen esimerkkinään käyttämät elokuvat hyödynsivät narratiiveja, jotka hallitsevat länsimaissa käytyä julkista keskustelua pakolaisuudesta ja kansallisesta turvallisuudesta. Olennaista pakolaisten esittämisstrategioiden kannalta oli näiden oletettu syyllisyys tai viattomuus. Vihollisina näyttäytyvät olennot esitetään katsojalle olomuodoltaan ja ulkonäöltään vieraina ja uhkaavina. Viattomina näyttäytyvät pakolaiset puolestaan inhimillistetään katsojalle samaistuttaviksi, jol- 
loin katsojissa pyritään herättämään myötätuntoa pakenevia olentoja kohtaan. Elokuvissa käytetty positiiviseksi miellettävä esittämistapa ei ole kuitenkaan Dittmerin mukaan ongelmaton, sillä tällaiset kuvaukset feminisoivat pakolaishahmot ja esittivät nämä vailla mahdollisuuksia omaan toimijuuteen.

Kokonaisuudessaan kaksipäiväinen seminaari loi mielenkiintoisen katsauksen kulttuurintutkimuksen tarjoamiin mahdollisuuksiin tarkastella entisissä Neuvostoliiton maissa toistuvia tapoja käsitellä omaa geopoliittista asemaa. Omat kysymyksensä geopoliittisista narratiiveista puhuttaessa tuntui luovan eri väestöryhmien alati lisääntyvä kansallisvaltioiden väliset rajat ylittävä migraatio. Lievästä Venäjäpainotteisuudestaan huolimatta seminaariin oli onnistuttu saamaan tiivis mutta monipuolinen kattaus erilaisia näkökulmia ja lähestymistapoja. Rajatun kokoinen seminaari toimi hyvin myös formaattina, sillä se tarjosi mahdollisuuden joustavampaan aikatauluun, jolloin pienet tietotekniset vaikeudetkaan eivät syöneet tilaa sessioiden päätteeksi syntyneiltä keskusteluilta.

Eeva Kuikka

\section{Postereita ja teknopuhetta Aleksanteri-konferenssissa 2019}

Lokakuun 23.-25. Helsingin yliopistolla kokoontui jälleen vuotuinen Aleksanteri-konferenssi. Konferenssin teema oli teknologia, kulttuuri ja yhteiskunta Euraasian alueella. Konferenssi järjestettiin jo yhdeksännentoista kerran ja se onkin muodostunut tärkeäksi vuotuisten kohtaamisten paikaksi Venäjän, Itä-Euroopan ja Euraasian alueeseen keskittyvälle monitieteiselle tutkijayhteisölle. Perinteisesti Aleksanteri-konferenssi tuo Helsinkiin runsaan joukon tutkijoita kautta maailman, tänä vuonna yhteensä kolmestakymmenestä eri maasta. Kaikkiaan yli puolet tämän vuoden noin kolmestasadasta osallistujista olivat ulkomaisista organisaatioista, erityisesti Venäjältä.

Ohjelma sisälsi yli viisikymmentä paneelia, joiden lisäksi konferenssiväelle tarjottiin mahdollisuus osallistua esimerkiksi opaste-

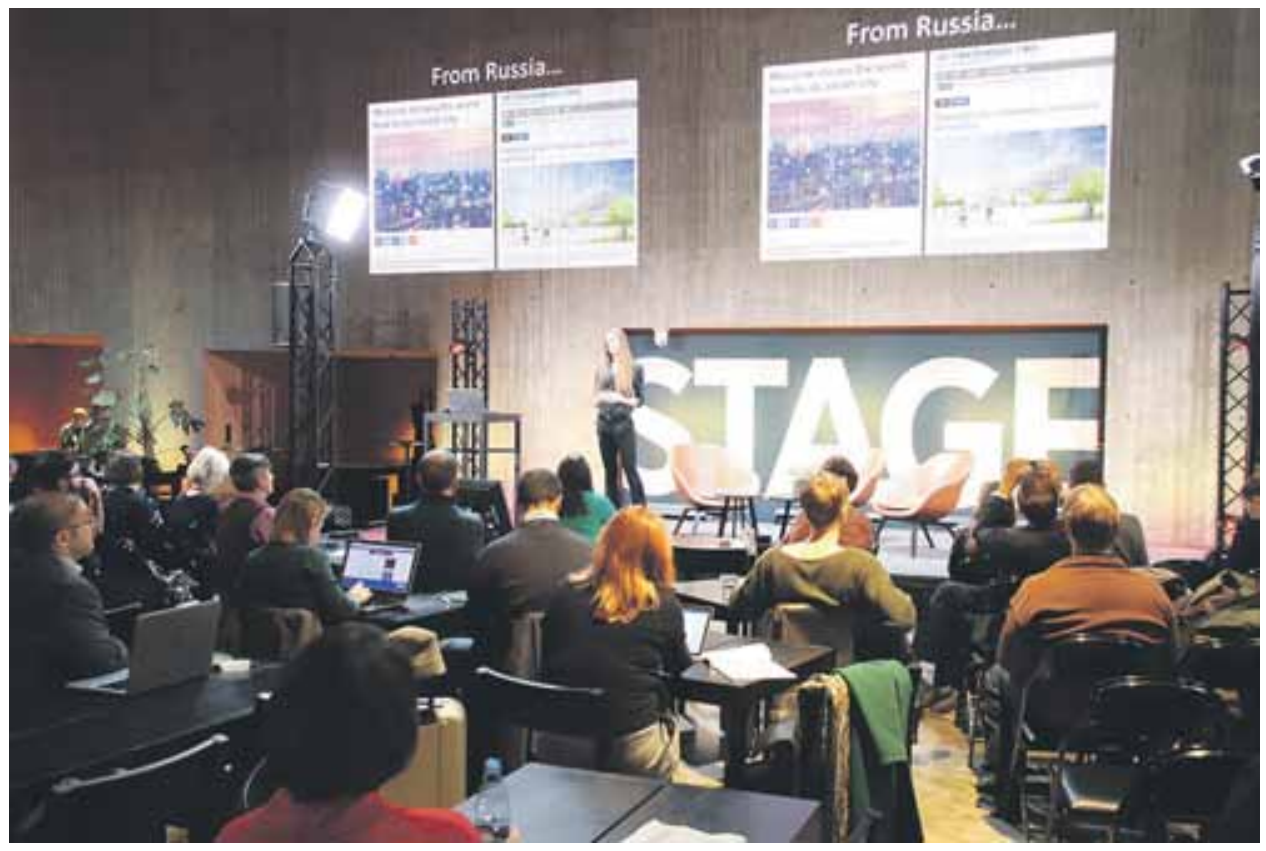

Aleksanteri-konferenssin keynotet valtasivat myös Tiedekulman Stagen. Natalie Koch (Syracuse University, USA) luennoi älykaupungeista ja teknofetisismistä Euraasian alueella. 